\title{
付加機能を複合した住宅作品の空間構成 SPATIAL COMPOSITION OF DWELLING COMBINED WITH ADDED FUNCTION
}

\author{
ホンソッピョ*, 塚本由晴** \\ Seogpyo HONG and Yoshiharu TSUKAMOTO
}

\begin{abstract}
The aim of this study is to clarify the spatial composition of contemporary Japanese houses that have functions other than a dwelling. First, problems of discussion were analyzed on following 4 aspects. Where is the location of the addition functional part and buffer domain in the site? What relations do they (the addition functional part and buffer domain) have on ground level? What is the circulation line feature of the buffer domain? Where does locate the buffer domain in the housing space, interior or exterior? Secondly, relations of the housing part, the addition functional part and buffer domain are represented by diagrammatizing division of volume of the whole construction just as a tree diagram. Finally, by arranging analyzed results as above, we extract typology of data having common feature.
\end{abstract}

Keywords : Added Function, Combination, Buffer Domain, Spatial Composition, Typology 付加機能，複合，緩衝部，空間構成，類型

1. 序

\section{1 研究の背景及び目的}

1920 年代に始まった戸建て住宅は、仕事をする地域と住む地域を 分ける都市計画的なゾーニングに基づいた核家族だけの空間へと純 化されていく傾向をもっていた。近年は、都市化による敷地の細分 化により家に人を招き入れる設えもなくなり、内に閉じがちになっ ている。そして、そのことがコミュニティの紐帯を弱め、無縁社会 と呼ばれる環境の遠因となっていることは憂慮に值する。時代を遡 れば、家の中にも商いや生産の場があり、使用人も多数出入りし、 書生や居候がいたことと比較すると、現代の住宅は寛容さを失って きたと言える。この傾向を批判的に乗り越えるために住宅が付加機 能を複合することは一つの方策となりうる。建築家による住宅作品 には、純粋に住居機能のみを有する住宅ばかりではなく、アトリエ や店舗、貸事務所といった住居以外の機能を併せもつものも少なく ない。そうした建築は純粋な居住のためにつくられた住宅とは異な る空間的なしつらえを持っているはずである。その構成の特徴を体 系的に捉えることは、これからの住宅のあり方を提案するうえで有 効な知見をあたえるだろう。そこで本研究では、住居機能以外の付 加機能を含む住宅 (以下、付加機能型住宅注1) ) を対象に、その構成
類型を抽出しその特徵を明らかにすることを目的とする。

\section{2 研究方法と概要}

研究資料としては、現代日本の建築ジャーナリズムの代表的なも のの一つである、1986 年から 2010 年までの『新建築』及び『新建 築住宅特集』に掲載された別荘や週末住宅を除く付加機能型住宅作 品 94 作品を対象とした (付表)。

各資料の付加機能には、アトリエ (32)、事務所 (24)、店舗（11）、 スタジオ (8)、ギャラリー (7)、教室 (6)、ホール、医院 (4) などで ある（表 1）。付加機能型住宅の空間は、基本的に住居部と付加機能 部に分けることができるが、それら 2 つの部分のみによって構成さ れるものは 15 作品と少なく、79 作品で住居部と付加機能部に挟ま れてそのどちらにも属さずに両者を接続する緩衝部注2) と呼びうる空 間が認められる (図 1)。この住居部にも付加機能部にも属さない緩 衝部をもつことは、付加機能型住宅が抱える空間的問題を理解する 鍵といえる。なぜなら、付加機能型住宅の必要条件ではないにも関 わらず、多くの事例に緩衝部が見られるということは、その存在が 機能と複合する上での空間的な仕掛けを担っていると考えられるか らである。そこで本研究では、住居部と付加機能部だけでなく緩衝 部を加えた 3 者注3) の関係から付加機能型住宅作品の構成形式をとら
本稿は参考文献13)をもとに加筆・修正したものである。 東京工業大学大学院理工学研究科建築学専攻 博士課程・修士 (工学)

** 東京工業大学大学院理工学研究科建築学専攻 准教授・博士 (工学)
Graduate Student, Graduate School of Dept. of Architecture and Built Eng., Tokyo Institute of Technology, M. Eng.

Assoc. Prof., Dept. of Architecture and Built Eng., Tokyo Institute of Technology, Dr. Eng. 
えることにする注4)

付加機能部、緩衝部、住居部（図、表においては順に $\alpha, \beta, H$ と表記） の面積比は (表 2)、緩衝部<付加機能部<住居部 (42)、付加機能部 く緩衝部く住居部 (22)、緩衝部く住居部く付加機能部（13）となる構 成が多く、緩衝部がみられない事例の面積比は、付加機能部く住居 部（14）が大半を占めた。

各部の関係を捉えるにあたっては、前面道路に対する位置、エン トランスの有無といった動線的な関係と各部が全体のヴォリューム の分割の中でどのような重みづけをされているのかという空間的な 関係の二つの側面から分析注 5) し、それぞれの結果の組み合せの中に 成立する付加機能型住宅の構成類型を抽出すると共に、類型の比較 から住居部と付加機能部の関係を取り持つ緩衝部の性格を明らかに していく。

\section{3 既往研究及び本研究の意義}

付加機能を持つ住宅を題材とした既往研究には、片方らによる併 用住宅の寸み方と改善経歴の特質を論じるもの注 6)、鵜沢らによる店 舗併用住宅の外観に表れるエレメントや日中と夜間の稼働時間の差 異における視覚的変化を論じるもの注7)、八木らによる併用住宅の外 観表現にみられる構成要素に着目し、内部機能と外観表現の関係を

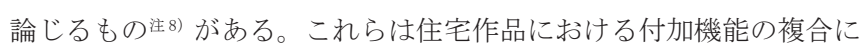
おける多様な建築的課題を明確にし、それぞれに特有な知見を導い ており、本研究の論点を整理する上で示唆に富むものである。しか し付加機能型住宅の中に住居部と付加機能部どちらにも属さない緩 衝部という第三の部分があることを指摘し、そこに機能を複合する 上での空間的な役割を見いだす本研究の視点は、これまで見られな いものである。

\section{2. 前面道路との関係からみた動線の接続パタン}

付加機能部・緩衝部・住居部は一つの住宅として動線によって接 続されていると共にどれも前面道路と接続し隣接することができる ので、前面道路からのエントランスがどこにあるか、前面道路に対 してどの部分が手前に配置をされているか検討することから付加機 能住宅の動線による性格を捉えることができる。

まず付加機能部と緩衝部の前面道路との関係は、前面道路側にあ るか否かで、表 ( f : 付加機能部 78/117・緩衝部 51/97) と裏 ( b : 付加機能部 39/117・緩衝部 46/97) の 2 種類になる（表 3)。さら に付加機能部と緩衝部の断面方向の配置は、上空 (U : 付加機能部 8/117・緩衝部 3/97)、地上 (G: 付加機能部 95/117・緩衝部 93/97)、(B: 付加機能部 14/117・緩衝部 1/97) である。付加機能部と緩衝部はそ の大半が地上にあるため、前面道路に対する配置は平面方向を主に 考えることにする。これより付加機能部と緩衝部の配置の組合せは、 共に表 $(30 / 79)$ 、付加機能部は裏で緩衝部は表 $(12 / 79)$ 、付加機能部 は表で緩衝部は裏 $(25 / 79)$ 、共に裏 $(12 / 79)$ として整理される。

また付加機能型住宅と前面道路の動線的接続は、付加機能部、緩 衝部、住居部のそれぞれに対するエントランスの組合せとして捉え ることにより（表 4)、付加機能部のみ (8)、緩衝部のみ (37)、住居 部のみ (12)、付加機能部と緩衝部がエントランスになるもの（10）、 緩衝部と住居部がエントランスになるもの (5)、付加機能部と住居 部がエントランスになるもの (18)、付加機能部、緩衝部、住居部が 共にエントランスになるもの（3）とまとめることができる。これよ
り緩衝部の約 7 割 (55/79)、がエントランスになることがわかった。 また緩衝部は内部 $(41 / 79)$ となるものが資料の半数を占めるが、 壁で囲まれた外部 $(26 / 79)$ 、屋根下の外部 $(12 / 79)$ となるものも少 なくない（表 5)。

これらの分析項目によれば、中京の家 (図2) は付加機能部は2 面 (南・ 東面）の前面道路に接してエントランスとなり、壁で囲まれた外部と なる緩衝部も 1 面の前面道路に接してエントランスとなり、層の異な る付加機能部と住居部間を階段で繫いでいるとみることができる。

前面道路に対する配置とエントランスの組合せは、理論的には 28 通 りあるが、ここでの資料では特定の組合せが繰り返しみられたのでこ れを前面道路との関係からみた動線の接続パタンとする（表 6)。

パタン $\mathrm{A} \sim \mathrm{H}$ は緩衝部が存在するものである。まずパタン A, B は緩 衝部が唯一のエントランスとなることで住居部、付加機能部、前面道 路を結びつけるものである。その内パタン A は緩衝部が表にあるもの で、付加機能部が表にあるもの（15）と裏にあるもの（12）が含まれる。 パタン B は緩衝部が裏にあるもので、付加機能部が表にあるもの (6)、 と裏にあるもの（4）が含まれる。

パタン $\mathrm{C} 〜 \mathrm{~F}$ は緩衝部のみならず他の部分もエントランスとなるも のである。その内パタン C は付加機能部と緩衝部が共にエントランス となるもので、付加機能部が表にあるのに対し緩衝部が表にあるもの (6)、緩衝部が裏にあるもの (5) が含まれる。パタン D は緩衝部と住居 部が共にエントランスとなるもので、付加機能部と緩衝部が共に表に ある (6)。またパタン E は付加機能部と緩衝部、住居部が共にエント ランスとなるもので、付加機能部と緩衝部が共に表にあるものである (3)。

次にパタン $\mathrm{F} \sim \mathrm{H}$ は付加機能部や住居部がエントランスになるもの である。パタン F は表にある付加機能部が唯一のエントランスになる ことで、前面道路から付加機能部を介して裏にある緩衝部と住居部に 繋がる (4)。パタン G は住居部が唯一のエントランスになることで、 前面道路から住居部を介して緩衝部と付加機能部に繋がるもので、緩 衝部が裏であるのに対し付加機能部が表 (3)、裏にあるもの (6) が含 まれる。これらは緩衝部を介さずに付加機能部と住居部が繋がる動線 （＊）を含むものである。パタン H は付加機能部と住居部が共にエン トランスとなるものである。緩衝部が裏にあるもので、付加機能部が 表にあるもの (7)、付加機能部が裏にあるもの (2) が含まれる。

パタン I は緩衝部が存在しないものである。付加機能部と住居部 (8) がエントランスになるものが多く、付加機能部が表にある傾向を示す。

\section{3. ヴォリュームの分割パタン}

次に付加機能部、緩衝部及び住居部が住宅の中でどのような重み づけがなされているのかを検討するために、空間の分割による階層 を樹形図を用いて分析する。壁 (W)による平面方向の分割や床 (W) による断面方向の分割を図式化した樹形図の枝分かれを上から 1 次、 2 次、・・、と数えることとし (表 7)、付加機能部・緩衝部・住居 部が明確に現れれば、それ以上の分割を検討しないことにする。例 えば分析例（図 3）においては、全体はまず壁に囲まれた外部の緩衝 部と内部空間に分割され、次に内部空間が床 (W) により上下 3 層に 分割されることで、1 階は付加機能部、2, 3 階は住居部となる。1 次 の分割で分けられた緩衝部にはそれ以上の分割が加えられないとい う分割手順の階層によって緩衝部は、空間としての重みづけがなさ 

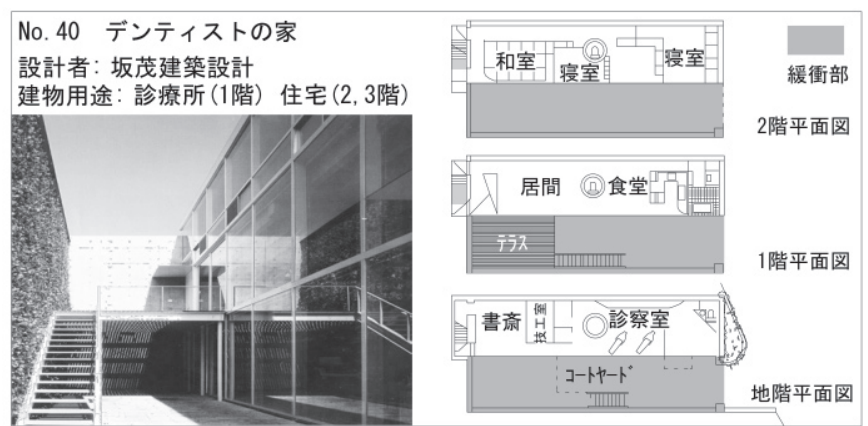

図1 緩衝部

表1 付加機能部の集計

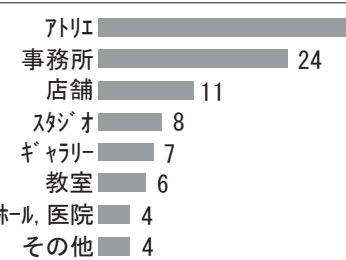

表 1 注）表中の数字は該当作品数を示し、表 1 は、数が 4 以上である付加機能だけ 明記している。ただし、合計は、 2 以上の付加機能部を含む作品の該当数も含まれ る為ので数である。また、その他の内訳は、倉庫，書庫，ライ゙顺，工場が各 1 である。 表 2 注）表中の数字は該当作品数を示し、 $\alpha$ は、付加機能部を $\beta$ は、緩衝部、Hは、 住居部を示す。作品ごとの各機能部の面積は、付表を参照。

表3 前面道路に対する配置と断面方向の配置

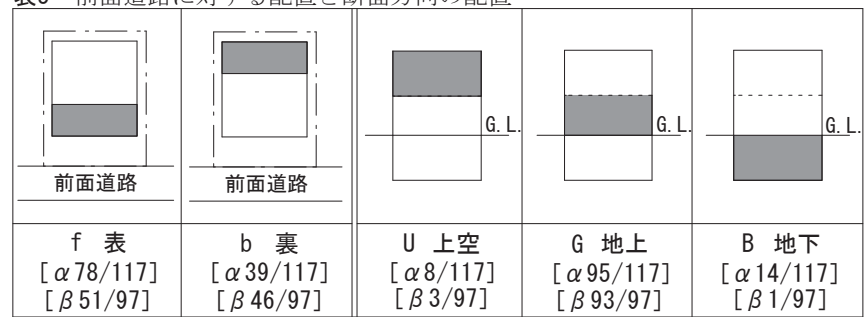

表 3 注）図中の数字は該当作品数を示す。ただし、作品数は 2 面以上 $[23 / 94]$ の 道路に接している作品の該当数も含まれるための心数である。

\begin{tabular}{|c|c|c|c|c|c|c|c|c|c|c|}
\hline \multirow{4}{*}{$\begin{array}{l}\text { I } \\
\text { 之 } \\
\text { 上 } \\
\text { ㄱ } \\
\text { ス }\end{array}$} & \multicolumn{2}{|c|}{ 数 } & \multicolumn{3}{|c|}{ e1 } & \multicolumn{3}{|c|}{ e2 } & e3 & 合計 \\
\hline & \multirow{3}{*}{ 箇所 } & $\alpha$ & 0 & & & 0 & & 0 & 0 & 39 \\
\hline & & $\beta$ & & 0 & & 0 & 0 & & 0 & 55 \\
\hline & & $\mathrm{H}$ & & & 0 & & 0 & 0 & 0 & 38 \\
\hline & \multicolumn{2}{|c|}{ 集計 } & 8 & 37 & 12 & 10 & 5 & 18 & 3 & 94 \\
\hline
\end{tabular}

表 4 注）図中の数字は該当作品数を示し、e はエントランスを示し、e1 はエントラ ンスが 1 つ、e2は 2 つ、e3は3つを示す。

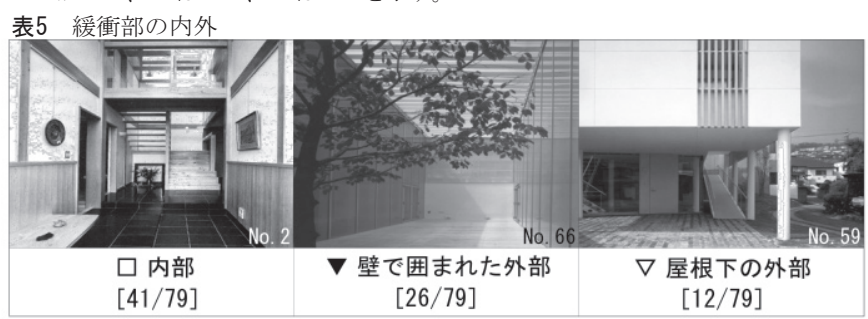

表 5 注）表中の数字は該当作品数を示す。

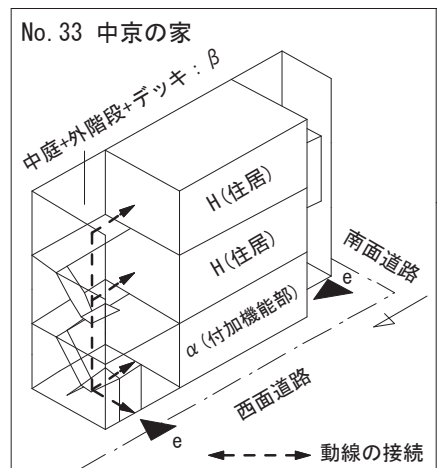

• エントランスの箇所 : $\alpha, \beta$

- $\alpha, \beta$ ともに「西面・南面」に対して $\alpha: \mathrm{fG}, \mathrm{fG}[$ 表・地上,表・地上] $\beta: \mathrm{fG}, \mathrm{bG}[$ 表・地上,裏・地上]

- $\beta$ の内外 : $\boldsymbol{\nabla}$ [壁で囲まれた外部]

- 面積比 : $\alpha<\beta<H$

2章 前面道路との関係からみた 動線の接続パタン

パタンC 表

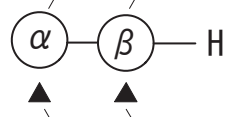

エントランス

図2 前面道路との関係からみた動線の接続の分析例

表6 前面道路との関係からみた動線の接続パタン

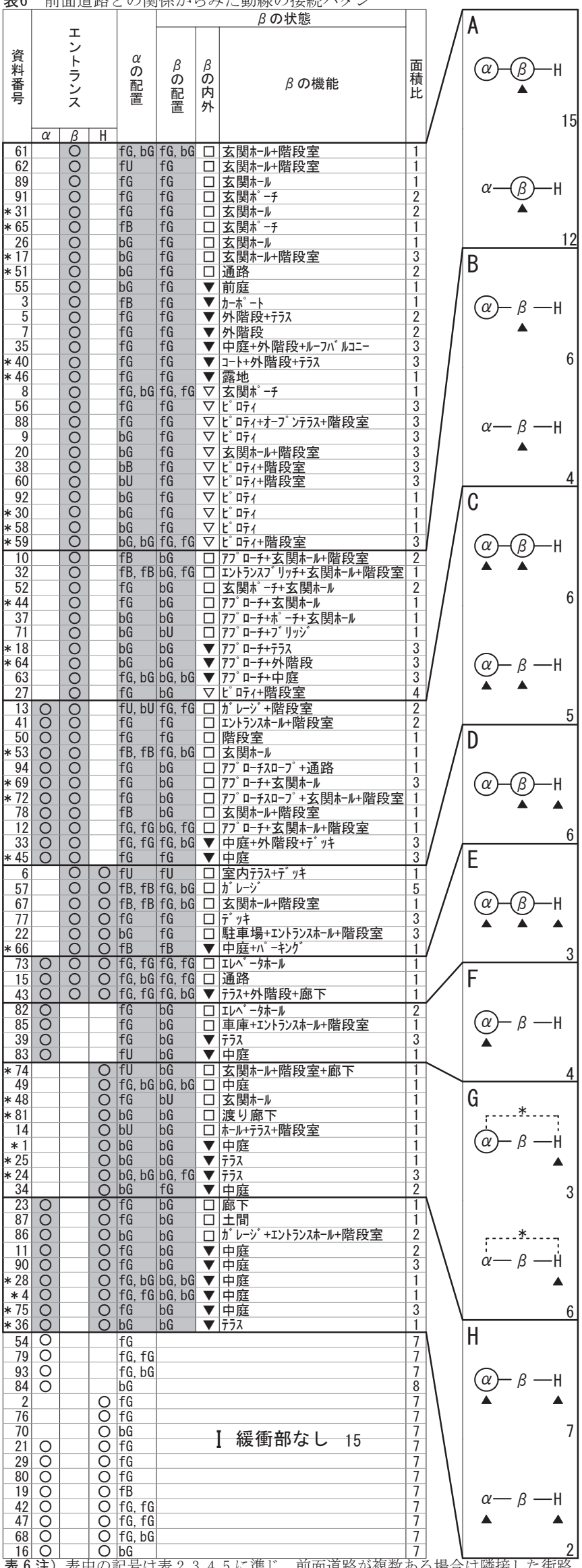

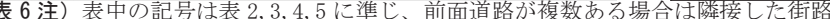
の大きなものから順に列記した。付加機能部と緩衝部のうち○印があるのは表を示 し、無いのは裏を示す。作品番号と図中の*は、緩衝部を介さずに付加機能部と住 居部がつながる動線を含むものを示す。 


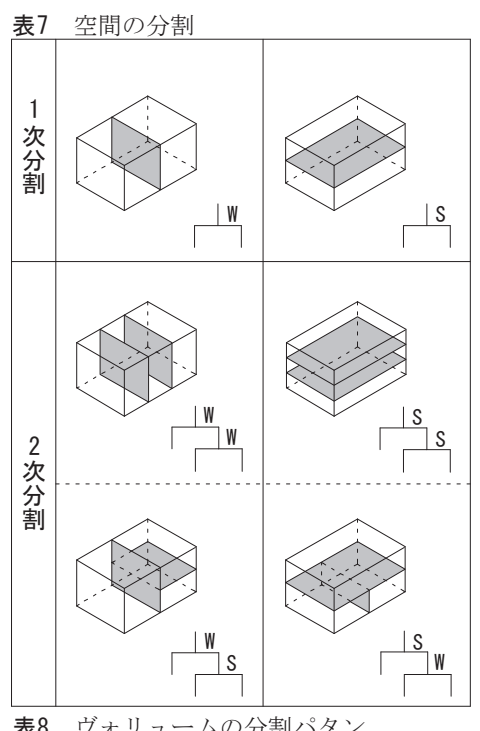

作品No. 33 中京の家
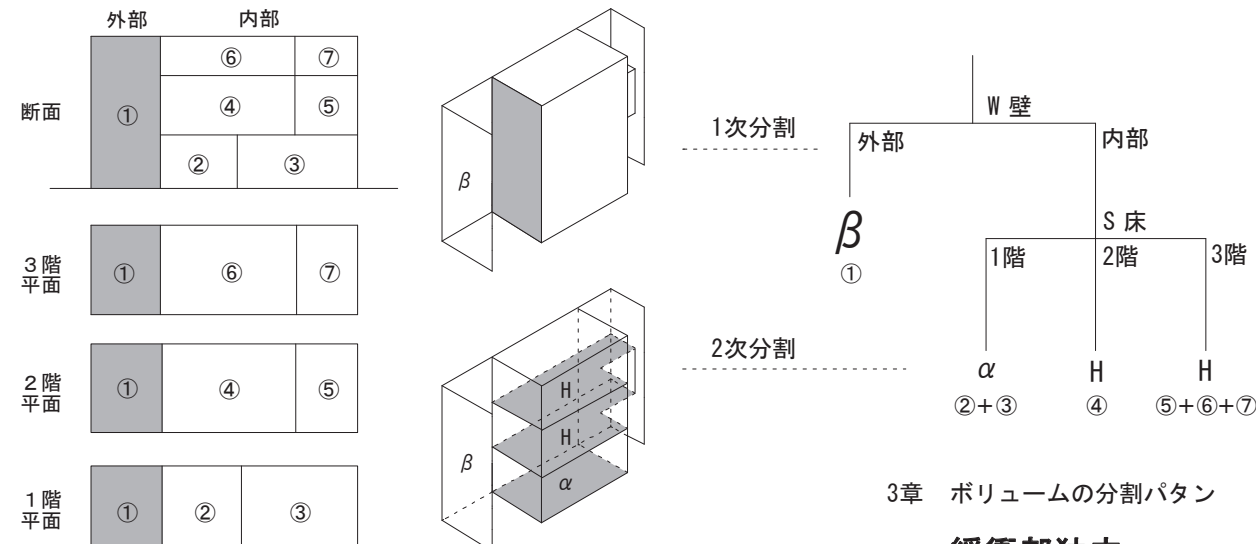

(1)外階段+中庭+テラス, (2)接客室, (3)土間, (4)寝室, (5)浴室, (6)ダイニングルーム, (7)テラス

3章 ボリュームの分割パタン

\section{緩衝部独立}

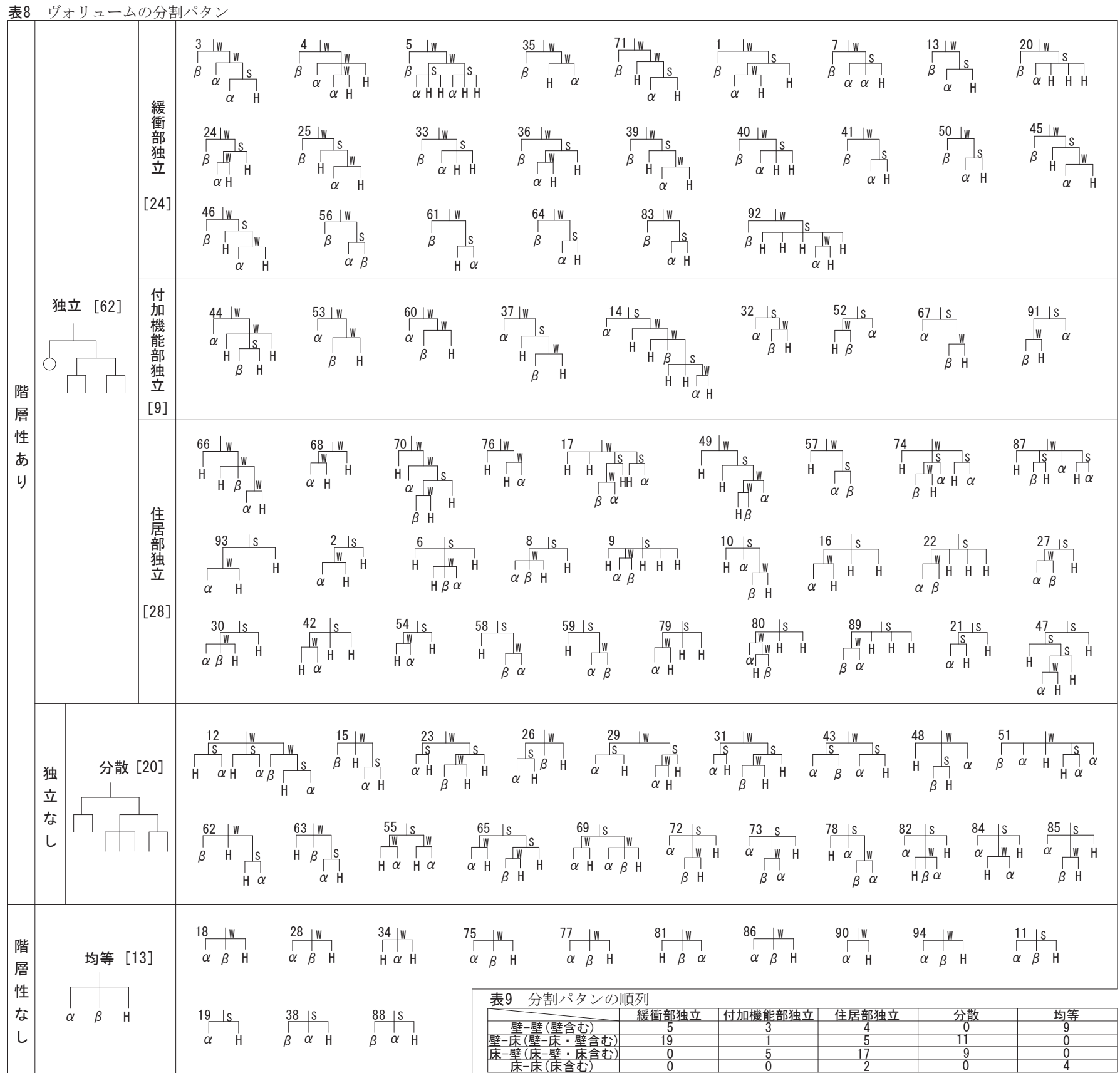

表8,9注） 表8の樹形図左上の数字は資料番号を示し［］丙の数は該当するする作品数を示す。また、表 9 の数は、該当する作品数を示す。 
れている。このように住宅作品が室に分割されていく順序をすべて の資料について検討し、これを比較することで樹形図に現したヴオ リュームの分割のパタンを得た（表 8)。

まず分割に階層性があるものの内、1 次の分割によって生じた部 分がそれ以降分割されないことで際立つパタンを独立 (62) として 整理すると、それらには、緩衝部独立（24）、付加機能部独立（9）、 住居部独立（28）がある。また独立のような大きな特徵がなく、付 加機能部・住居部および緩衝部が様々な枝に分散するパタンは分散 （20）である。次に 1 次で付加機能部・住居部および緩衝部に 3 分割 し、階層性がないパタンは均等（13）である。

分割の階数についてみると 1 次分割だけのものが 13 作品で、 2 次 まで分割されるものは 54 作品で大半を占め、3 次まで分割されるも のは 23 作品、それ以上分割されるものは 4 作品のみであった。つま りほとんどの作品が 3 次分割までで住居部、付加機能部、緩衝部に 分割される。しかし、3 次分割はほぼ壁による分割となり、差が生 まれない。そこで分割パタンの順列については 2 次分割までを問題 にすると 1 次が壁、2 次が床になる分割 (以下、1 次、2 次の順に壁 一床と記す）が 36 作品、次に床一壁（床-壁・床を含む）が 31 作品、 壁-壁が 21 作品（壁を含む）、そして床一床が 6 作品（床を含む）の 順に多くみられた。この分析の順列と各パタンの関係を検討すると （表 9）、緩衝部独立は、壁一床による分割が大半を占めるのに対して、 住居部独立は床一壁による分割が大半を占めた。付加機能部独立は 1 次で壁による分割と床による分割が同等にみられ、分散は壁-床や床 一壁といった 1 次と 2 次の分割が異なる傾向がみられた。

\section{4. 動線の接続とヴオリュームの分割による付加機能型住宅の構成類型}

前面道路との関係における配置と動線の接続による構成（接続パ タン) と、ヴォリュームの分割からみた構成（分割パタン）の重ね 合わせとして付加機能型住宅の構成形式を捉えるために、動線の接 続パタンを縦軸に、ヴォリュームの分割パタンを横軸にマトリック スを作成し、全資料を緩衝部の内外、ヴオリュームの分割の次数及 び順列とともにプロットした（表 10）。各マスはそれぞれ異なる付 加機能型住宅の構成形式を示し、マトリクスはその可能性の広がり を示すわけだが、実際の資料はこの中でいくつかのマスに集中する ことによって繰り返し用いられる類型化した形式 (以下、構成類型) であることを示している。そこで 3 資料以上の作品が集中寸る組合 せを付加機能型住宅の構成類型として以下に抽出する。

く類型ア、イ、ウ〉は緩衝部が道路側にあり、かつ唯一のエント ランスとなるものである。その内く類型ア〉は 1 次の壁による分割 で強調された緩衝部が道路側にあり、かつ唯一のエントランスとな ることで、前面道路から必ず緩衝部を介して付加機能部、住居部が 繋がるものである。付加機能部は事務所、診療所、店舗が多く前面 道路側にあるもののエントランスとはならない。道路側に設けられ た中庭のような壁で囲まれた外部空間であり、客などの外部からの 訪問者と居住者を分けない共通の場としての緩衝部となっている。

〈類型イ〉はまず一次の床による分割で住居部とそれ以外を上下 の層に分け、次に地上部分で壁により緩衝部と付加機能部を分ける もので、道路側にある屋根下の外部の緩衝部が唯一のエントランス となるものである。

〈類型ウ〉はヴォリュームの分割による各部の重みづけはないが
緩衝部が道路側にあり、唯一のエントランスとなるものである。裏 にある付加機能部は個人のアトリエやギャラリーとなる傾向がある。

く類型エ〉は付加機能部が 1 次分割で強調され、かつ道路側に位 置するものの裏にある緩衝部が唯一のエントランスとなるものであ る。

〈類型オ、カ〉は付加機能部と緩衝部がともにエントランスとなり、 しかも付加機能部が必ず道路側にあるものである。この緩衝部は必 ず前面道路から住居部に繋がる経路になることにより、住居部より の性格を持つと言える。そのうちく類型オ〉の道路側にある緩衝部 は一次の壁による分割で強調されるが、〈類型カ〉の緩衝部は裏に あり分割による強調もなされない。

く類型キ〉は道路側の緩衝部と住居部がともにエントランスとな るものである。住居部は前面道路に直接繋がるが、付加機能部は緩 衝部を介することになるため、付加機能部よりの緩衝部となってい る。

〈類型ク〉は道路側にある付加機能部と緩衝部、住居部全てにエ ントランスがあるもので、緩衝部のエントランスとしての役割は相 対的に弱く、勝手口のような性格を帯びる。またエントランスが分 散すると、ヴォリュームの分割も分散になるという対応関係がみら れる。

〈類型ケ〉は住居部が唯一のエントランスとなることで、前面道 路から必ず住居部を介して緩衝部、付加機能部に繋がるものである。 裏にある付加機能部には個人のアトリエやギャラリーが多く、一次 分割で強調された壁で囲まれた中庭のような緩衝部が、住居部との 距離を確保する。また緩衝部を介さずに付加機能部と住居部が繋が る動線も認められることから、一般の住宅に近い付加機能型住宅の 類型といえる。

く類型コ〉は壁で均しく分割された付加機能部、緩衝部、住居部 のうち、付加機能部と住居部がエントランスとなり、壁で囲まれた 中庭のような緩衝部で動線的に接続されるもので、緩衝部の住居部 と付加機能部を分ける役割が強調されている。

く類型サ〉は緩衝部が存在しないもので他の類型と明確に区別す るものである。一次の床による分割で住居部が強調されるもので、 付加機能部と住居部が共にエントランスになるものが多く、付加機能 部が表にある傾向を示す。

序でも述べたように、緩衝部は付加機能型住宅において住居部と 付加機能部が複合する上での空間的な仕掛けを担っている。そこで、 これらの類型どうしの比較によって緩衝部の性格の違いを述べる ( 図 4)。緩衝部が唯一のエントランスとなることで動線的に際立つ のがく類型ア、イ、ウ、エ〉の緩衝部である。また 1 次で壁により 分割され、強調された外部空間が全体から空間的に際立つのがく類 型ア、オ、ケ>の緩衝部である。付加機能部と住居部の間で距離を とる働きをし、付加機能部と住居部を隔てるのがく類型ケ、コ〉の 緩衝部である。また道路から住居部までの動線となるもので、住居 部よりの緩衝部となり動線的に住居部を奥に位置づけるものがく類 型才、カ>の緩衝部であり、付加機能部よりの性格となり動線的に 付加機能部を奥に位置づけるのがく類型キ〉の緩衝部である。また 1 つの緩衝部にこれらの性格が重衫られるものには、空間的に際立 ちかつ住居部よりのものく類型才〉、空間的に際立ちかつ付加機能 部と住居部を隔てるものく類型ケ〉があり、空間的かつ動線的に際 
表10 前面道路との関係からみた動線の接続とヴォリュームの分割からみた付加機能型住宅の構成類型

\begin{tabular}{|c|c|c|c|c|c|}
\hline $\begin{array}{l}\text { ヴォリュー台 } \\
\text { 動線の接続 }\end{array}$ & 緩衝部独立 & 付加機能部独立 & 住居部独立 & 分散 & 均等 \\
\hline 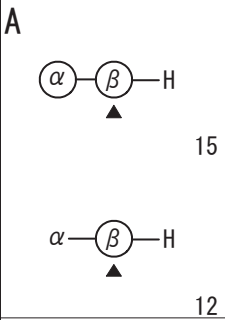 & 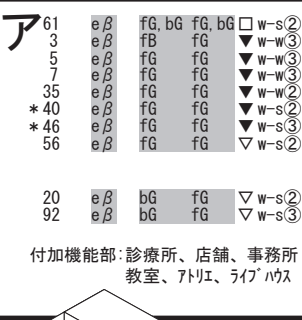 & $\begin{array}{lllll}91 & \mathrm{e} \beta & \mathrm{fG} & \mathrm{fG} & \square \mathrm{s}-\mathrm{w} 2\end{array}$ & 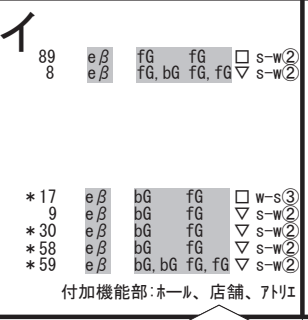 & 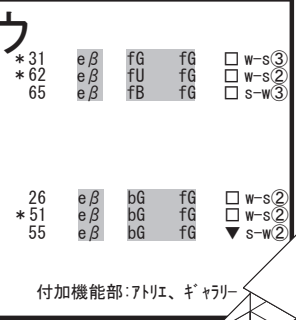 & 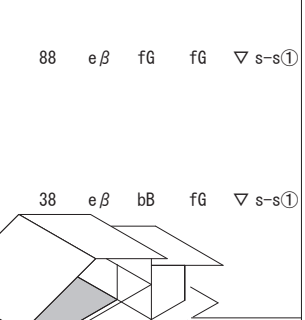 \\
\hline $\begin{array}{lll}\alpha-\beta-H & \\
& & \\
& & \\
\alpha-\beta-H & \\
4 & 4\end{array}$ & 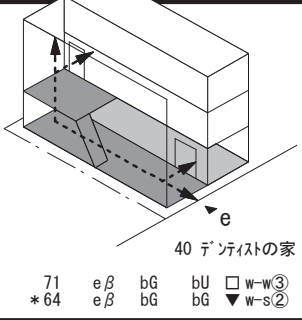 & e $\beta \quad f B, f B b G, f G \square,-\gamma$ & 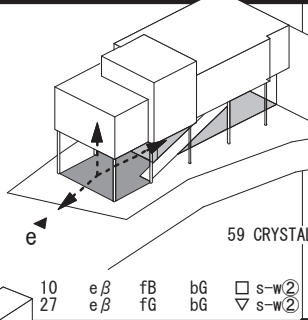 & $f G, b G b a, b G \leq w-s, 2$ & 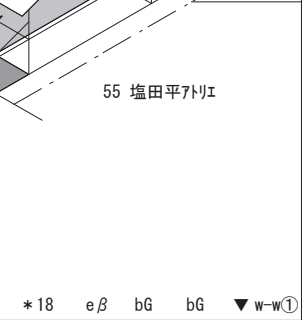 \\
\hline 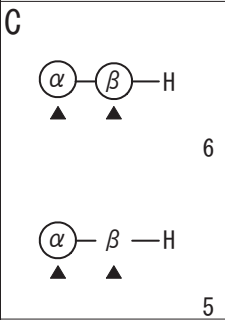 & 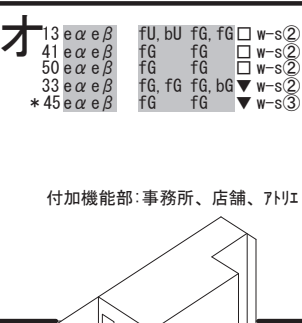 & & & 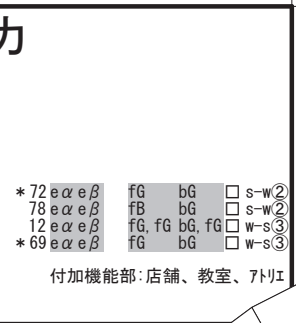 & $94 \mathrm{e} \alpha \mathrm{e} \beta \quad \mathrm{fG} \quad \mathrm{bG} \quad \mathrm{w}^{\mathrm{w}-\mathrm{w}(1)}$ \\
\hline 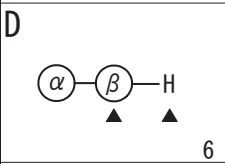 & & & 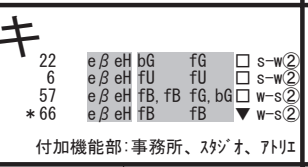 & & 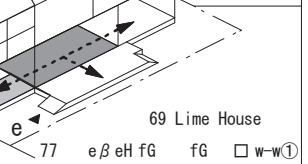 \\
\hline 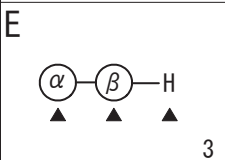 & & & & 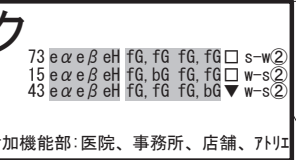 & \\
\hline (a) $-\beta-H$ & $\begin{array}{ll}b G & \nabla \\
b G & \nabla-s(3 \\
b-s(2)\end{array}$ & & & 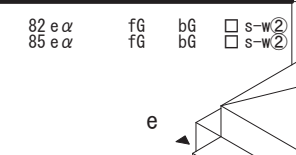 & \\
\hline 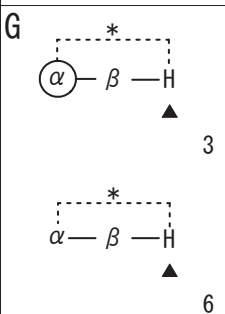 & 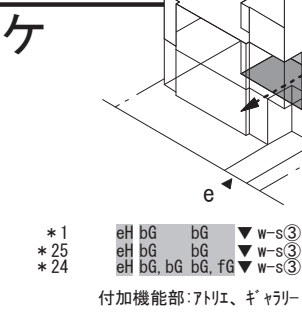 & $\begin{array}{ll}b G & \square s-w 5\end{array}$ & 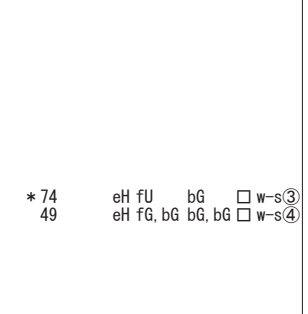 & $* 48$ eH fG bU $\square w-s(2)$ & 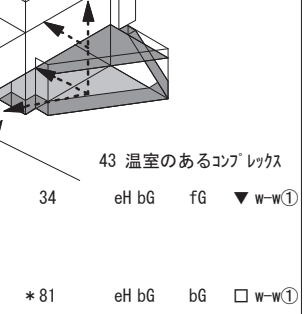 \\
\hline 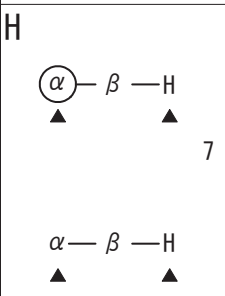 & 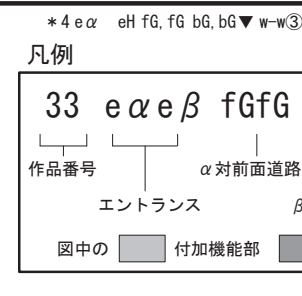 & 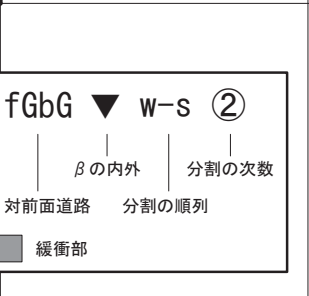 & bG $\quad \square w-s(2)$ & $23 \mathrm{e} \alpha$ eH $\mathrm{fg}$ & 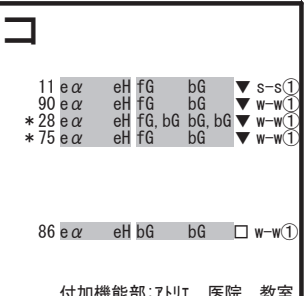 \\
\hline $\begin{array}{l}\text { I } \\
\text { 緩衝部における } \\
\text { 動線の接続なし } \\
\quad(\beta \text { なし })\end{array}$ & $36 \mathrm{e} \alpha$ eH bG $\quad$ bG $\quad \boldsymbol{V} \mathbb{w}-\mathrm{s}(3)$ & & 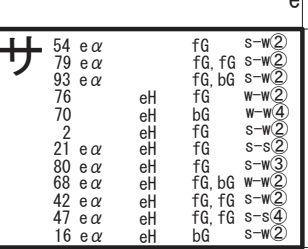 & $\begin{array}{ll}f G & w-133 \\
b G & s-w 2) \\
s-w 2\end{array}$ & 19 e $\alpha \quad$ eH \\
\hline
\end{tabular}

表10注）表中の記号は表 $3,4,5,6,8,9$ に準じ、動線の接続パタンでHを除く $\alpha$ と $\beta$ において○があるものは表、ないものは裏を示す。 


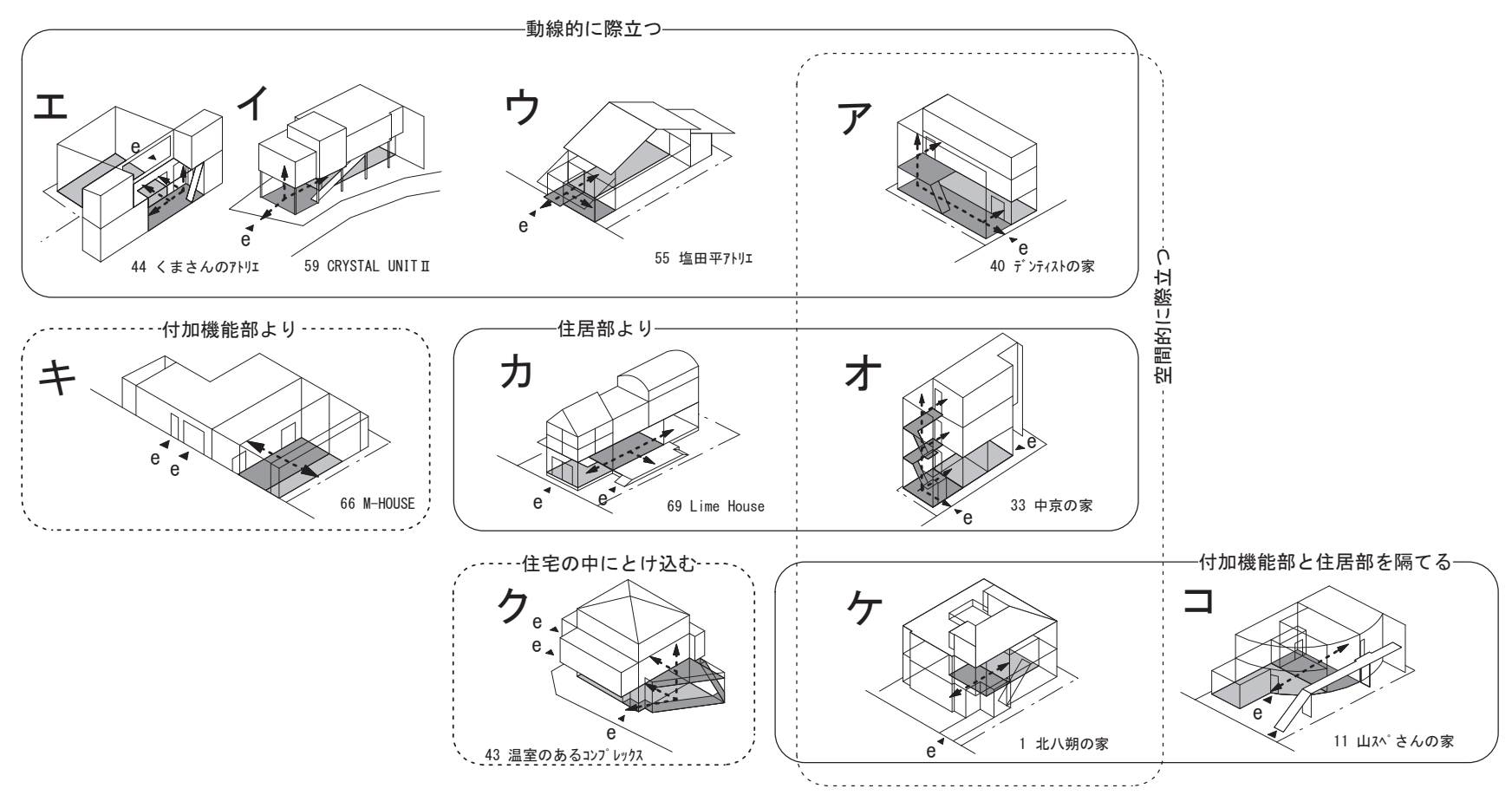

立つものく類型ア〉があり、それとは対照的に、空間的に強調され ず動線的にも外と繋がれていないことから住宅の中にとけ込んだよ うな性格を持つく類型ク〉がある。このことから、緩衝部の性格に は「動線的に際立つ」、「空間的に際立つ」、「付加機能部と住居部を 隔てる」、「住居部より」、「付加機能部より」、「空間的に際立ちかつ 住居部より」、「空間的に際立ちかつ付加機能部と住居部を隔てる」、 「空間的かつ動線的に際立つ」、「住宅の中にとけ込む」があることを 明らかにした。

\section{5. 結}

以上、本研究では現代日本の付加機能型住宅作品の空間構成の検討 を行った。まず付加機能型住宅の住居部と付加機能部の間に位置する ことで動線的に両者を接続している緩衝部の存在が認められた。次に 前面道路に対する付加機能部と緩衝部の配置とエントランスの有無 を検討し、前面道路との関係からみた動線の接続パタンを抽出した。 さらに付加機能部、住居部および緩衝部の住宅の中での重みづけを 空間の分割から検討し、ヴォリュームの分割パタンを抽出した。最 後に、これらのパタンの重祆合わせから、付加機能型住宅の空間構 成の類型とその特徵を明らかにした。さらに類型どうしの関係から、 緩衝部の性格には「動線的に際立つ」、「空間的に際立つ」、「付加機 能部と住居部を隔てる」、「住居部より」、「付加機能部より」、「空間 的に際立ちかつ住居部より」、「空間的に際立ちかつ付加機能部と住 居部を隔てる」、空間的かつ動線的に際立つ」、住宅の中にとけ込む」 があることを明らかにした。この結論は、住宅を都市に開いていく ために緩衝部が有効であることを示し、働き方の再編やコミュニティ の再生に向けた住宅建築の多機能化に対して新たな知見を与えるも のである。
注

注 1）「付加機能型住宅」は本論文で新しく定義する用語である。広辞苑には 店舗、事務室等といった機能が住居機能とともに存在する住宅を「併用住宅」 と呼ぶことがあるが、概して併用住宅の定義が曖昧であるのが現状である。 たとえば本論文で資料として用いた『新建築住宅特集』誌では、住居以外の 機能を併せ持つ住宅に対し「併用住宅」「店舗十住宅」、「アトリエ付き住宅」、 「住宅+アトリエ」といったように作品によって様々な名称が用いられてお り、実際にそれら似通った名称をもつ住宅間での構成における違いあるいは 機能における違いが一体何であるかを簡単な手法ではっきりと認識すること はできない。そこで本研究では住居以外の機能を含む住宅を「付加機能型住 宅」と呼んでいる。

注 2）既往研究による緩衝部に類する表現はつなぎ空間、緩衝領域、緩衝空 間、空間等、様々で、参考文献 3) では建物境界と街路境界との間の空間を、 参考文献 4) では敷地内部の公的空間と敷地外部の私的空間を、参考文献 5) ではアプローチ空間のセミ・パブリック領域とエントランスコートのセミ・ プライベート領域をまとめたものをともに「中間領域」と呼び、参考文献 6) では街路と住居の内部私的空間をつなぐものを、参考文献 7) では、内部で も外部でもない中間的な空間である軒下・ピロティ空間を「緩衝空間」と呼 んでいる。本稿では住居部と付加機能部に挟まれて動線として両者を接続し ている空間を緩衝部とした。

注 3） 本研究では、住居部、付加機能部、緩衝部を加えた 3 者の関係から付 加機能型住宅作品の構成形式を捉える為、以下のように 3 者を定義する。 住居部：住居としての一的な機能を満たす部分。

付加機能部：住居とは異なる、住居に対して付加的な機能を持つ部分。 緩衝部：住居部と付加機能部に挟まれてそのどちらにも属さずに両者を接続 する部分。

注 4）分析を簡略化するために隣接している複数の緩衝部は一つにまとめて 取り扱う。もし隣接した緩衝部ではなく数力所に緩衝部が分散して現れる場 合は、より重要度の高い方の緩衝部を扱う。より重要度の高い緩衝部とはよ り多くの住居部・付加機能部と隣接しょり多くの動線を含む。これは住居部・ 付加機能部のみに対する動線関係だけでなく、前面道路との動線関係におい ても同じである。

注 5）本研究の研究方法の一部はこれまでの筆者らの研究において試みられ てきたものをさらに展開するものである。住宅の中での付加機能部・緩衝部・ 住居部の重みづけに関しては、筆者らによる空間の分割についての研究参考 
文献 8) を参考してる。また動線による空間の性格に関しては動線により室 の連結を問題にした参考文献 9) を参照している。

注 6) 参考文献 10) 参照

注 7）参考文献 11）参照

注 8）参考文献 12）参照

\section{参考文献}

1）広辞苑, 岩波書店, 第四版, 1998

2) 北山恒、塚本 由晴、西沢 立衛： TOKYO METABOLIZING, TOTO 出版, 2010.7.

3）三浦 彩子、八木 幸二、是永 美樹、内山 森 : 商業密集地における建築 に付随する中間領域の空間構成と利用，日本建築学会大会学術講演梗概集 F-2, pp. 1167-1168, 2004.7.

4）宇野 弘蔵、有馬 隆文、萩島 哲、坂井 猛 : 来街者の行動を誘発する空間 構成に関する研究：商店街における公と私の中間領域に着目して, 日本建 築学会大会学術講演梗概集 F-1, pp. 1165-1166, 2004.7.

5）清水 肇：集合住宅における公私の中間領域の形成：段階的領域形成を意 図して計画された平良市馬場団地、平良団地の実態調査，日本建築学会大 会学術講演梗概集 E-2，pp. 245-246，2003. 7 .

6）荻野 隆博、長田久美、渡辺猛、八木幸二、那須 聖、茶谷 正洋: ジャ イサルメルの伝統的都市住居における空間構成と生活様式（その1）：住 居の緩衝空間の段階的構成, 日本建築学会大会学術講演梗概集 E-2, pp. 2122, 1998.7.

7）濱本 紳平、積田 洋、徐 華、井上 嘉文: 空間構成による類型化分析： 緩衝空間の構成に関する研究 (その 1 ), 日本建築学会大会学術講演梗概集 E-1, pp. 813-814, 2010.7.

8）塚本 由晴、坂本一成：現代日本の住宅作品における空間の分割 一住宅 建築の構成形式に関する研究一, 日本建築学会計画系論文集, 第 478 号, pp. 99-106, 1995. 12.

9）貝島 桃代、坂本 一成、塚本 由晴 : 動線による室の連結 一現代日本の建 築作品における動線の空間構成に関寸る研究-, 日本建築学会計画系論文集, 第 498 号，pp. 131-138，1997.8.

10）清水 肇、坂東 亜希子、片方 信也、小伊藤直哉、岩崎 滋彦、古谷勲、 杉谷 久美子：京都市中心部における併用住宅の住み方と改善の経歴に関寸 る研究, 日本建築学会計画系論文集, 第 456 号, pp. 189-198, 1994.2. ・坂東 悪希子、清水 肇、小伊藤 直哉、片方 信也 : ライフステージにみる 住宅改善行為につながる住み方に関する研究 一京都市都心部の併用住宅集 積地域の調査から-, 日本建築学会計画系論文集, 第 462 号, pp. 117-125, 1994. 8.

11）具志つや子、鵜沢 隆 : 店舗併用住宅における外観的特徵と昼夜変化の研 究：東京都 神宮前、墨田・東向島、北沢を事例として, 日本建築学会大会 学術講演梗概集 E, pp. 341-342，2010.7.

12）油谷 千佳、八木 幸二、是永 美樹、川合 英介 : 併用住宅における内部 機能との関係からみた外観表現, 日本建築学会大会学術講演梗概集 F-2, pp. 693-694, 2004.7.

13）照井 崇、塚本 由晴: 付加機能型住宅の構成形式, 日本建築学会大会学 術講演梗概集 F-2, pp. 587-588, 1999. 7.
付表 資料作品リスト

\begin{tabular}{|c|c|c|}
\hline 資料 & $\begin{array}{l}\text { 揭載 } \\
\text { 年 }\end{array}$ & 作品名 \\
\hline & & \\
\hline 1 & jt8804 & 北八朔の家 \\
\hline 2 & jt8809 & 江南の家 \\
\hline 3 & jt8810 & ハ禅・・コグレッス \\
\hline 4 & jt8901 & H型コートハス \\
\hline 5 & jt8908 & TRANS \\
\hline 6 & jt8908 & 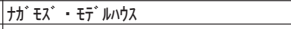 \\
\hline 7 & jt8910 & CLOUD NINE \\
\hline 8 & jt9001 & 中村邸 \\
\hline 9 & jt9003 & COSMOS \\
\hline 10 & jt9003 & 下北沢のアートスペース \\
\hline 11 & jt9003 & 山スペさんの家 \\
\hline 12 & jt9004 & YAOKICHI \\
\hline 13 & jt9103 & DEC0-都市住宅・1991- \\
\hline 14 & jt9104 & 八雲のス㚈 オ \\
\hline 15 & jt9107 & 伊東邸 \\
\hline 16 & jt9107 & 木場の家 \\
\hline 17 & jt9108 & 声楽家の家 \\
\hline 18 & jt9203 & 成城・路地の家 I ・ II \\
\hline 19 & jt9206 & 瀬川邸 \\
\hline 20 & jt9206 & 日本橋の家 \\
\hline 21 & jt9209 & 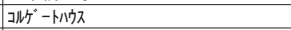 \\
\hline 22 & jt9211 & Three Steps House \\
\hline 23 & jt9211 & 鳥山の家 \\
\hline 24 & jt9212 & 壳中天地吕/陣内訃I \\
\hline 25 & jt9305 & 上総の家 1 \\
\hline 26 & jt9305 & 上総の家2 \\
\hline 27 & jt9306 & レ゙ルス \\
\hline 28 & jt9306 & 保谷本町の归ニ听 \\
\hline 29 & jt9309 & 甲 SHELL koura \\
\hline 30 & jt9310 & 堺町の家 \\
\hline 31 & jt9312 & 国府台のP怆 \\
\hline 32 & jt9401 & 住宅NNo. 14 筑波黒の家 \\
\hline 33 & jt9401 & 中京の家 \\
\hline 34 & jt9403 & K HOUSE \\
\hline 35 & jt9403 & 市川邸 \\
\hline 36 & jt9403 & 住吉山手の家 \\
\hline 37 & jt9404 & クロスプランの家 \\
\hline 38 & jt9404 & 南砂の家 \\
\hline 39 & jt9405 & Barn-3 \\
\hline 40 & jt9406 & $\bar{\tau}^{\circ}$ `ティイスト家 \\
\hline 41 & jt9407 & 学芸大学_YK HOUSE \\
\hline 42 & jt9410 & TADZI0/平磯の町屋 \\
\hline 43 & jt9410 & 温室のあるコクプックス \\
\hline 44 & jt9501 & 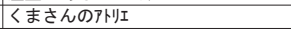 \\
\hline 45 & jt9501 & 下鴨の家 \\
\hline 46 & jt9501 & 大島の家 \\
\hline 47 & jt9503 & 大塚邸 \\
\hline 48 & jt9505 & 2つの空 \\
\hline 49 & jt9506 & 藤枝・能舞台のある家 \\
\hline 50 & jt9509 & 八门人117 \\
\hline 51 & jt9509 & 梅林の住宅 \\
\hline 52 & jt9510 & 朔 \\
\hline 53 & jt9511 & 西原の家 \\
\hline 54 & jt9601 & ISOBE STUDIO\&RESIDENCE \\
\hline 55 & jt9601 & 塩田平P怆I \\
\hline 56 & jt9602 & 識名の家 \\
\hline 57 & jt9603 & HOUSE IN HOUSE \\
\hline 58 & jt9604 & ガラス屋の家 \\
\hline 59 & jt9608 & CRYSTAL UNIT II \\
\hline 60 & jt9608 & 太宰府の住宅 \\
\hline 61 & jt9609 & トீミ/1996 \\
\hline 62 & jt9612 & 住宅/移゙、、生け花作家のための \\
\hline 63 & jt9612 & 白贀の家 \\
\hline 64 & jt9702 & 街なかの家 \\
\hline 65 & jt9702 & 小平セヒビングルス \\
\hline 66 & jt9709 & M-HOUSE \\
\hline 67 & jt9712 & 常磐台の住まい \\
\hline 68 & jt9801 & 駒場のコートハス \\
\hline 69 & jt9803 & Lime House \\
\hline 70 & jt9809 & 耳岩の家 \\
\hline 71 & jt9811 & 七里ガ浜の木箱 \\
\hline 72 & jt9811 & 今治の家 \\
\hline 73 & jt9901 & F5 \\
\hline 74 & jt9906 & 祐天寺丁邸 \\
\hline 75 & jt9908 & 夏椿の家 \\
\hline 76 & jt9911 & 那須の住宅 \\
\hline 77 & sk0006 & ONE \\
\hline 78 & sk0008 & 鶴見のP怆・住居 \\
\hline 79 & sk0102 & $\mathrm{T} \cdot \mathrm{N}$-HOUSE \\
\hline 80 & jto201 & A_residence+studio \\
\hline 81 & jt0407 & いわむらかずお絵本の丘美術館忡I \\
\hline 82 & sk0603 & QUIC0神宮前 \\
\hline 83 & sk0605 & 箱の家-112［神宮前計画］ \\
\hline 84 & sk0605 & ハウス\&アトリ・・ザ \\
\hline 85 & sk0610 & NYH \\
\hline 86 & jt0611 & WHITE BASE \\
\hline 87 & jt0705 & WEP下北沢 \\
\hline 88 & sk0705 & 白山通りのいえ \\
\hline 89 & jt0706 & TROLLEY \\
\hline 90 & jto804 & k邸 \\
\hline 91 & sk0804 & 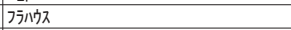 \\
\hline 92 & sk0811 & 力多゙ラスの家 \\
\hline 93 & jt0906 & 7アン・片 \\
\hline 94 & sk1002 & アトリ・・ビスタドール \\
\hline
\end{tabular}

（2012年 1 月 10 日原稿受理， 2012年 3 月28日採用決定） 